\title{
Child marriages in Turkey with different aspects
}

\author{
MaideGök ${ }^{1}$
}

\begin{abstract}
Child marriages are one of the most important reasons of gender inequality in the family in Turkey, as well as a widespread social problem we face is seen all over the world ${ }^{2}$. This situation increases the need for child marriages to be viewed from a different dimension to the phenomenon and to reveal all aspects of this problem. The issue of child marriages are being addressed in the literature in recent years has been the subject of research in different disciplines, but most of the work is focused on a single dimension of child marriage or depending on the specific area it seems they are trying to identify child marriage. In current study, although carried to contribute to the debate on the concept of child marriage, legal issues, medical, economic, social and political dimensions are presented with an integrated approach. In present study, it has been found that child marriages are an important result of observed gender inequalities in social, political, and economic life and child marriages have been found to cause to continue the gender inequality on women's lives. However, the cultural codes, values and inequalities, the deterioration of the family structure, social movements, and migration are seen to have an impact on child marriages. In this study, many suggestions are offered to solve the problem of child marriages such as ensuring gender equality in childhood, abandoning conditioning on gender roles, and increasing education level and the law enforcement.
\end{abstract}

Keywords:Child Marriages; Gender Roles; Gender Inequalities.

\section{Introduction}

It is seen that the challenge of child marriages is more intensively observed in different historical processes and cultural structures, frequently starting to become a current issue in recent years. Child marriages are common social problem in Turkey as well as over the world and the United Nation's "if necessary precautions are not taken, in 2020 more than 140 million girls will marry as children" prediction increase the number of studies focusing on the problem. It is observed that most of these studies address the problem form a legal point and some of the works are done in the field of public health. Early age marriages in Turkey has been the subject of research in terms of health (Karaşahin and Ergün, 2010; Özcebe and Biçer, 2013; Yıldırım, İnal and Tinar, 2005), from psychological aspect (Soylu and Ayaz, 2013), from legal aspect (Oğuzman and Dural, 1998; Çelik, 2005; Akın, 2015), and from socio-cultural aspect (Aydemir, 2011; Elmac1 and Ertem, 2010; Erol and Duman, 2015; Burcu and Sirma, 2015). Several studies in the literature (Singh and Samara,

\footnotetext{
1 Yrd.Doç. Dr., mgok@bingol.edu.tr,University of Bingol.

2 This article is extended version of presented paper on IX. European Conference on Social and Behavioral Science on 3-6 $6^{\text {th }}$ April 2016 in Paris.
} 
1996; Hervish and Feldman-Jacobs, 2011) stated that the most important cause of child marriages is education, and some studies (Çakmak, 2009; Açıkgöz and Yusufoğlu, 2012) pointed out that the most important cause of the problem is economically.

Studies carried out in the international arena show a significant relationship between country's level of development and girls' early age marriages. Children are seen as an economic burden for families and they are removed from their family, friends and training agency and left to the tutelage of people they never knew. This situation causes a life by the effect of others power and control which led to the violation of children's rights can lead to the emergence of many negative situations. For the elimination of such breach, the implementation of new protective legislation in the legal field and the protection of children's rights and prevention of child marriage are seen as solutions. It is seen that the proponents who argue the problem can only be eliminated with the regulations in the field of law do not take into account many institutions especially families which form social structure.

However, in some communities, with girls' marriages they are seen as a income opportunity, and required to be used as a domestic service worker show that family is the most important institution for the child marriages. In a similar way, girls gender discrimination experience in the family, they could not benefit equally in many areas of resources and opportunity, even they are not registered to the population registry, and this situation caused by an inability to identify exactly child marriage rates in many countries, especially in Turkey. Moreover, using religion as a legitimate power in the forced marriages and announcement of women's dramatic end news through the media who are getting married in their child age, show that multiple actors are effective to the emergence of the problem.

In the studies which are dealt with sociological perspective, these gender inequality context problems are seen as the most important causes of child marriages (Burcu and Sirma, 2015). In this study, the child marriage issue in Turkey is analyzed by bringing together the findings of the studies in the literature with a holistic perspective, it is tried to find an answer to the question whether the competence of their way to address the problem of existing work, and tried to reveal unknown aspects of the problem. Additionally, with current study it is aimed to be a source for future studies in the area and to make contribution to the problem's solving process by drawing attention to the personal and social consequences.

\section{Definitions and Discussions on Child Marriages}

Marriage at child age or child marriage is considered as at least one of the two people's under the age of eighteen merging their lives by legal or unofficial way with the marriage contract. On the other hand, child marriages are defined as marriages made without completing the mental and physical development or early marriages. In the definition, it is stated that certain maturity as physical, spiritual, and mental levels are required for an individual to think and live as an adult (Çakır, 2013:41).

It is discussed that girls who are getting married at child age cannot be seen as "bride" because marriage requires certain level physical, emotional and mental maturity. Despite this, in daily life it takes attention that the term of "child brides" is used instead of "child marriages". The problem with making a negative connotation in people leads to discussion of this concept should be defined by which to comprehend. Therefore, child brides, child marriage, early marriage and child marriage concepts can be used instead of the other. Although the discussions on the concept, the concept of child marriages should be used in defining the problem it is particularly desired by official institutions. 
Another controversial issue is the debate about what is the exact age limit for being considered in the category of child marriage. According to international regulations, all marriages are made under the age of eighteen are counted as child marriages, for the people who are looking from the medical terminology perspective, the process up to twenty years is accepted as a process not reached sufficient maturity for marriage. In Turkey, there is also no exact age criterion for the identification of child marriage in the field of law. It is also discussed that which age should be used to categorize the child marriage. Below, it is introduced how the concept of child bride changes in the Turkish legal system (Akin, 2015).

- According to Turkish Civil Code girls who are not completing age of 17.

- According to Child Protection Law, girls who are not completing age of 18.

- According to Turkish Penal Code girls who are not completing age of 15 are not considered as child brides.

This inconsistency between the laws in terms of age of marriage is considered as one of the most important factors that affect the prevention of early marriage. In the case of upgrading child's age, it can be estimated that average age of child marriages can be lower.

\section{Child Marriages in terms of Socio-economic}

Observing lots of negative results of child marriages make it mandatory to discover the reasons of those kinds of marriages. In order to determine and solve the problem, first of all it is necessary to find out the sources of the problem. Along with the causes of early age marriages differ from one culture to another, main causes can be stated as follow:

- Socio-economic causes (poverty, welfare level)

- Low education level

- Cultural structures (traditions, customs, and religious beliefs)

- Gender (women's conditioning to get marry and being mother)

- Domestic violence

- Immigrations (transferring rural values to city)

Among these reasons, poverty and lack of education are seen as the most important causes of early marriage in particular is widely observed in the East and Southeast. In their study Açıkgöz and Yusufoğlu (2012) found that women are in a more disadvantaged position than men in society and experienced poverty more than men. In their study it is stated that financial difficulties of working in rural or urban areas, the lack of educational opportunities, and the desire of contributing to the family income cause the high rate of poverty risk for women who are not adequately educated. In traditional societies, some continued traditions such as "dowry" and "milk money" may cause child marriage with more economic causes and such practices may lead to an increase in child marriages by showing as legitimate to the society. According to Family Structure Survey (2006), the rate of dowry application which is essential for marriage in Turkey is $16.8 \%$. While this ratio is $13 \%$ in urban areas has increased to $23.5 \%$ in rural areas. Dowry is observed to vary according to the age. While dowry ratio was $28.7 \%$ for 65 and older years, it was $7.9 \%$ in the $25-34$ age group, and in the 18-24 age group it was determined as $10.2 \%$.

Family Structure Survey carried out in 2011 shows that practice of dowry rate is $15.6 \%$ in Turkey. While $12.6 \%$ of dowry practices in the city, this rate increases $22.8 \%$ to the countryside. Compared with previously conducted Family Structure Survey (2006) data, it is observed that rate to give dowry in Turkey dropped $1.2 \%$ in the five-year period. In these studies, significant relationships between the families' socio-economic level and dowry practices have been identified. For example, while in the upper socio-economic groups dowry application rate is $4 \%$, this rate rises to $29.9 \%$ in the lowest socio-economic groups. 
Beside economic reasons education also increases the rate of child marriage. In particular, decrease in the proportion of the education level of parents and children result with the increase the rate of early marriage (TNSA, 2008). However, early age marriages can occur due to several reasons such as domestic sexual assault, nonmarital pregnancy, and domestically observed gender inequalities. Especially in patriarchal society structure men are in the position of decision-making and it may cause child marriages to pass from generation to generation and mother who experienced early age marriage cannot save their children from same fate.

Beside this situation which causes inequality between men and women, belief systems and cultural codes also has been observed to cause early marriage. Especially, the common idea of satisfying girls' emotional, sexual, and economic needs in a manner appropriate to the religion, marriage relationship is necessary and protecting girls' virginity increase the number of child marriages in the society. On the other hand, the investor model which emerged with the idea that men will take care of them when they are getting older causes the gender discrimination and may lead to the understanding that it is not necessary the education of girls and promote the understanding that marriage is salvation for women. However, if girls lose their parents, marriage can be seen as a solution.

\section{Early Marriages as a Social Problem in the World and in Turkey}

Early marriage problem is not peculiar to Turkey and is seen all around the world. It brings lots of questions herewith. For example; why such a common social problem cannot be prevented? Why other problems which are caused by that problem are ignored? Many researchers try to describe child marriage problem, but cannot give enough information to the solution of that issue. In fact, after looking at the reality levels of child marriage issue, it can be stated that there is insensitivity about the problem, lack of common sense, and the lack of effective and practical legal work. When it is thought that every year fourteen million girls live this process and considering the numbers of some of the countries are high that will be seen this determination is not false. For example, according to UNICEF (2011) data, while marrying under the age of 18 worldwide the proportion of women was 34\%, in less developed countries such as Afghanistan, Angola, and Bangladesh the rate was 45\%. Early marriage is highest in Chad with 68\%, Bangladesh and Mali with 65\%. However, According to Plan Organization's (2011) survey conducted in 2011, rate was $72 \%$ in Chad, $66 \%$ in Bangladesh, and 52\% in Mozambique. These data show child marriage decrease in some countries.

In Turkey, according to the Family Structure Survey (2006) although one of every three marriages was said as child marriages, having many religious marriages and being out of record make it difficult to fully determine the number of child marriages. Nevertheless, in 2011, the marriage rate is calculated as $7.2 \%$ under the age of 18 . According to the report prepared by the Association of Women's Human Rights-New Ways in 2004 and supported by the Turkish Penal Code Women's Platform, the rate of marriage without official document is $7.7 \%$ and people only religious marriage is $7.4 \%$. According to information received from General Directorate of Population and Citizenship Affairs, child marriage rate is $15.5 \%$. It is possible to reach to the actual rate of child marriage in Turkey when rate of the officially unmarried people and rate of the people only have religious marriage are added to the official rate. When viewed from this point, the child marriage rate in Turkey is considered to be at least $30-35 \%$. So, in Turkey, one of every three marriages among currently married girls was done when they were child (Özcebe and Biçer, 2013).

According to the 2008 Turkey Demographic and Health Surveys, the age of marriage for girls in Turkey has dropped to 12 years. The findings of the study show that $53 \%$ of unofficially marriage people lived in eastern and southeastern part of Turkey. In the same report, it is also reported that 
born children are registered in the name of mother-in-law because of real mother's underage problem. The most common marriage types in the East and Southeast part of Turkey are "dowry marriage", "blood price marriage", and "bride exchange marriage". When the fact of majority of the families who are getting married their daughters by using those three ways are under the absolute poverty rate is taken into consideration, the relationship between frequency of child marriage and family's wealth level appears obviously.

\section{Child Marriages in terms of Mental and Body Health}

It is a controversial issue that many of the children who are getting married at the beginning of puberty may not have a healthy sex life. Because sexuality is a multidimensional concept including social, cultural, biological and physical and associated with cognitive, emotional, intellectual, development entity that provides social cohesion and to be associated with the love of sharing draw attention to the problem may be caused by early marriage (Derman, 2008). Particularly forced marriage, have not reach to sexual maturity and marriage of children who do not feel love sharing may lead to physical and mental health problems on both married children and children they bring into the world.

In many studies about effects of early marriage on the development of adolescents and adolescent sexuality, negative aspects of early marriage are discussed. Although the girls' completions of their development steps vary, marriage of children who do not complete their development has multiple negative results. According to Derman (2008), sex involves three key elements: identity, desire and behavior. He states that emergence of these three elements depends on the stage development of adolescents. These development stages are divided into three parts: physical, sexual, and psychosocial and the completion of the development of these three stages differs for girls and boys. In the early adolescent stage the most important event for sexual identity is the lack of psycho-social development in the quick sexual and mental development. By taking into account these development stages, early marriage's negative effects on the adult development are listed as follows (Derman, 2008, 2016):

- It creates difficulty in the transition from the concrete to the nonphysical.

- Regression forms on the maturation of development stages.

- Early married girls perceive themselves more positively in adulthood compared to early maturing men, without internalizing problems, interpersonal stress increased the struggle cannot be more successful.

- Early marriage hinders awakening, vision, and want on the adolescent regarding sex.

- Especially those who are nearest confidence in the people reduce and self-development is prevented.

In addition to the problems experienced by those of you who get married at an early age mental effects of early marriage has also attracted attention. According to Soylu and Ayaz (2013)'s study findings, early married girls $20.8 \%(n=9)$ attempted suicide, $14.6 \%(n=7)$ is suffered physical violence / abuse by mates, and $27.1 \%(\mathrm{n}=13)$ is suffered by emotional violence / abuse.

Table 1- Mental Problem Types in Early Marriages.

\begin{tabular}{|c|c|}
\hline MENTAL PROBLEM TYPES & $\mathbf{\%}$ \\
\hline Major depression & 20.8 \\
\hline Adjustment disorder & 14.6 \\
\hline Traumatic stress disorder & 8.3 \\
\hline Postpartum depression & 2.1 \\
\hline TOTAL & $\mathbf{4 5 . 8}$ \\
\hline
\end{tabular}


(Source:Soylu and Ayaz-2013; Erol and Duman, 2015:65).

On the other hand, to cope with the problems of adolescence is defined as a difficult process in itself, trying to tackle the problems that they are children of the marriage may lead to bigger problems. In the research it was determined that $14.6 \%$ of early age married girls was exposed to physical, $27.1 \%$ of them was exposed to emotional abuse, while $10.4 \%$ was determined as sexually abused by her husband or another person (Soylu and Ayaz, 2013).

When we focus the risks and health problems faced by those who marry at an early age, it can be seen in many serious health problems can arise with gynecological diseases. These include giving birth at an early age, frequent pregnancies, sexually transmitted infections, preeclampsia, anemia, head-pelvic disproportion, the risk of a difficult birth, severe hemorrhage, postpartum complications (vesikovajinal / rectovaginal fistulas and most importantly maternal deaths. Depending on the child age marriage, stopping on the growth and development stages, to be deprived from the health care and family planning services, an increase in the risk of sexually transmitted diseases (HIV, hepatitis, etc.), and gynecologic cancer, genitourinary injuries, lacerations (incontinence-stool in the coming period problems) arise (Kurt and Canbulat, 2013). Such risks are reported as more visible at the pregnancy. For example, in a study, 1800 adolescent pregnant women's faced problems have been identified as; premature birth, low birth weighted infants, miscarriage, severe anemia (Yıldırım et al., 2005:249-52).

As well as these potential risks and problems faced by the families, risks and problems that babies faced can reach very serious level. For example, low birth weight, premature birth, acute infections, accidents, mental retardation, abuse and neglect, such as leaving the baby and infant mortality can be stated as these kinds of problems (Family Structure Survey, 2006). By considering that 5\% of 1519 age group adolescent women in Turkey have child or they are pregnant with their first child, it is not difficult to guess where high incidence of these problems. Promising situation is that adolescent fertility rate tends to fall over the years. According to research from 1993, while this rate was 10.2 $\%$ between 1988 and 1993, this rate decreases to 4.6\% between 2008 and 2013. According to the results of TNSA's 2013 results, 5 out of 100 pregnancies are induced abortion. Overall, there has been a significant decrease in the level of abortions in the 20-year period of the study. In the 1993 survey, 18\% of the abortion rate declined to $5 \%$ in the 2013 survey (Women in Turkey Report, 2015). It is estimated that due to contraceptive studies abortion rate reduced in Turkey.

\section{Child Marriages in Law}

It is seen that Turkey supports studies for the protection of children's rights to both national and international level. Convention on the Rights of the Child opened for signature in 1989 by the United Nations and it has introduced a large part in the World Summit for Children in 1990. Turkey signed the convention at the World Summit for Children which was held at the United Nations' Headquarters (Çelik, 2005). Besides, with the Convention on the Elimination of all Forms of Discrimination against Women (CEDAW) which was signed in 1985 by Turkey, all the basic rights in the context of equality between women and men, as free to choose a spouse, and marriage with free and full consent are fully protected. In this agreement no way is considered as legal for early age marriage of children and some other articles regarding determination of the age of marriage and the keeping of compulsory registration of marriages take place in the official records were defined.

Despite in these studies child marriage is considered as a human rights violation, in Turkey especially inconsistency of laws in determining the age limit of child marriages, leaving fruitless all struggle against to marry at an early age. According to Turkish Civil Code, the girl who married 
before reaching the age of seventeen is considered as child bride. However, according to the general provision in the law of a young girl who is under the age of seventeen can be married to the judge's decision in extraordinary circumstances. Child Protection Act defines children as "even though being adult at an earlier age, who have not completed the age of eighteen". Citizens under the age of eighteen, have not complete their physical, mental, moral, social and emotional development, are seen as individuals open to be neglected or abused and these individuals are described as "children who need protection".

In the Turkish Penal Code's Article 104, in paragraph 1 it is stated that "without force, threat and fraud, if person has sexual intercourse with a child over the age of fifteen, on the complaint, he-she shall be punished with imprisonment from six months up to two years." If a girl has reached the age of fifteen, married in the sociological sense (not legally), spouses who have sex with this girl, not punished without complaint. Turkish Penal Code implicitly keeps age of marriage under the age of eighteen. If the girl is getting married after filling age of fifteen, this cannot be seen as child marriage. Considering all these mentioned, it is possible to say that in the Turkish legal system the description of the concept of child marriage changes according to the law (Özcebe and Sar1, 2015:26). However, it is necessary to legally investigate with child marriages which are violation of child rights, children's which rights are taken away. While 4500 cases were opened in 2002 in Turkey about sexual abuse against children, this number rose to 17,500 in 2012. It can be observed that girls deprived of their most fundamental rights and freedoms by getting married at child age. At the beginning of those rights, the right of living free, the right to decide about their own life, the right to education and, perhaps more importantly, the right to live their childhood can be stated. In the international documents it is stated that "decision for marriage and fertility are human rights of individual", but families often intervene to use this right in Turkey (Başak and Ateş, 2015).

Nevertheless, especially in the international documents under the "Youth Sexual and Reproductive Rights" title 12 rights are underlined. These are the right to life, liberty and security of person, the right to equality, right to privacy, the right to freedom of thought, knowledge and the right to education, the right to choice in marriage and family building issues, the right to freedom from torture and ill-treatment, the right decision and participate in politics, to benefit from scientific progress right, the right to protection of health and health care, and the right to take the decision to have children (Akın, 2015:15). Despite international legislation, it is much thought provoking the prevalence of child marriage and the discovery of 62 million across the world. Because the fact is that many of these are not new provisions contained in international legislation and appear to be aimed at preventing child marriage in absolute terms.

\section{Conclusion}

As a result of early marriage girls' education rights are obstructed, their access to the financial resources is limited, their risk of exposure to violence is increasing, and both their body and mental health are imperiled. Married girls are unable to complete their education and as a result they are deprived of their labor rights (Aktaş, 2013:9). However, child marriages, as they often take the form of illegal marriages, child brides, are being deprived of the right to gain with civil marriage contract. In this situation woman is exposed to more intense sex discrimination and gender inequality leads to sustained in multiple areas.

In the 2013 World Economic Forum Gender Gap Index Report on Social Values, Turkey ranks $120^{\text {th }}$ of 136 countries. According to the report, Turkey, $104^{\text {th }}$ in education, $103^{\text {rd }}$ in political participation, $59^{\text {th }}$ in health, and $127^{\text {th }}$ in economic participation. The cause of being back in the list is the reason of the low status of women in society and also a result of it. In regions where status of women is low, child marriages are more frequent. However, children who are getting married at 
early ages cannot create a successful socialization process of passing an autonomous identity and cannot create self-perception, break off and alienated from social life, and are found to have an unsafe environment perception.

All of these female-oriented problems against the civil society carried out by the organization campaigns and projects, studies for gender equality in primary education, Grand National Assembly of Turkey Women and Men Equal Opportunities under the Commission on Early Marriages have been established Subcommittee and removed the mention of the gender gap in legislation that is an important step for Turkey in the fight against child marriage. Despite this important step and consistent with legal marriage age in the United Nations Convention on the Rights of the child in practice it is seen not achieve the desired success in the prevention of early marriage. Therefore, some proposals are given below:

- In order to educate poor family girls, official institution supervision should be made and educational assistance should be given to these families.

- Effective control methods should be developed to reduce poverty and studies must be done to increase the participation of women's employment.

- New legislative and policy measures should be increased; discrepancy between the laws related to determine the age of marriage should be abolished.

- Regional / local reports should be prepared to determine all aspects of the problem.

- Cooperation studies should be increased (between media, schools, local governments, and health units)

- Various activities for the elimination of the problem should be carried out (seminars, conferences, as the information channels such panels as the number of films and cinema and theater performances).

- Starting from child age, gender equality tried to be provided in many areas.

- Gender role conditioning works must be prevented (in the media, in educational institutions, in family and in cultural values).

- Successful prevention models on early marriage from other countries should be transferred to the country.

- Application of family counselors should be expanded and family protection centers should be established.

- Birth control education should be applied in early marriages and if pregnancy has been happened, it should be considered under the risky pregnancies.

- During adolescent pregnancies, with a multidisciplinary approach process should be conducted with medical assistance, social services, care, and nutrition.

- By increasing the number of studies about children of early age married women, social consequences of this problem should be made visible.

If above mentioned recommendations will not be taken into account, women's secondary position will not change in the society, they will not come to a decision-maker, and therefore will not be able to prevent their girls from living in the same process as them. However, women without having rights on getting married and their family-building, in fact face with violations on freedom, living, security, decision-making, as well as the right to health, education, and the right to benefit from social services and it is expected to increase child marriage rates in the future. 
Gök, M. (2016). Child marriages in Turkey with different aspects. International Journal of Human Sciences, 13(1), $2222-2231$. doi:10.14687/ijhs.v13i1.3795

\section{References}

Açıkgöz, R. and Yusufoğlu, Ö. Ş. (2012). Türkiye'deYoksulluk Olgusu ve Toplumsal Yansımaları. Insan ve Toplum Bilimleri Araştırmalar Dergisi,1(1):76-117

Akın, A. (2015). Erken yaştaki evlilikler. (pp.11-23). Evlilik Çocuk Oyunu Değill: Çocuk Evlilikler (Ed. Çolakoğlu, B.E.) Anka Yayınları: Ankara.

Ergenlerde Cinsellik ve Erken Evliliklerin Ergenlerin Gelişimlerine Etkileri. Evlilik Çocuk Oyunu Değil: Çocuk Evlilikler Sempozyumu, 7 Mart 2014, Ankara.

Aktaş, G.(2013). Yoksulluğu Ev İçinden Tanımlamak: Kadın Bakış Açısından Yoksulluk. Uluslararası Katılımlı 7. Ulusal Sosyoloji Kongresi Bildiriler Kitabı (3 Kitaplık Set) / Ed. Tuna M. Muğla: Muğla Sttkı Koçman Üniversitesi, 1-11.

Aile Yapısı Araştırması. (2006). T.C Başbakanlık Aile ve Sosyal Araştırmalar Genel Müdürlüğü, Ankara, 2010: 21-41.

Aile Yapısı Araştırması. (2011). T.C. Aile ve Sosyal Politikalar Bakanlığı.Retrieved 10 March 2016 from http://www.athgm.gov.tr/upload/athgm.gov.tr/mce/2013/taya_kitap_butun.pdf

Avşar, F. (2015). Çocuk yaştaki evliliklerde yaşanabilecek obstetric ve jinekolojik sorunlar. (pp.72-84). Evlilik Çocuk Oyunu Değil: Cocuk Evlilikler (Ed. Çolakoğlu, B.E.) Anka Yayınları: Ankara.

Aydemir, E. (2011). Evlilik mi Evcilik mi. Erken ve Zorla Evlilikler Cocuk Gelinler. USAK Rapor NO: 11-8, Ankara.

Başak,S. and Ateş, A. (2015). Önsöz. (pp.3-7). Evlilik Çocuk Oyunu Değil: Cocuk Evlilikler (Ed. Çolakoğlu, B.E.) Anka Yayınları: Ankara.

Burcu, E. and Sırma, C..S. (2015). Evlilikte sosyo-ekonomik faktörlerin önemi. (pp.33-57). Evlilik Cocuk Oyunu Değil: Cocuk Evlilikler (Ed. Çolakoğlu, B.E.) Anka Yayınları: Ankara.

Çakmak, D. (2009). Türkiye'de Çocuk Gelinler, Birinci Hukukun Gençleri Sempozyumu-Hukuk Devletinde Kişisel Güvenlik, Bildiri Tam Metinler E-Kitabı.Retrieved $10 \quad$ February 2016 from http://www.umut.org.tr/HukukunGencleri/TamMetinlerSunular/DirenÇakmak.

Çelik, C. (2005). Çocuk Kavramı ve Medeni Hukuk Açısından Çocuk Haklarının Tarihi Gelişimi. E-Akademi, Hukuk, Ekonomi ve Siyasal Bilimler Aylhk Internet Dergisi, 36.

Derman, O. (2016). Adölesanlarda Stk Karşılaşılan Sorunlar. Retrieved 10 March 2016 from https://www.google.com.tr/\#q=Derman\%2C+Orhan+ppt

Derman, O. (2008). Ergenlerde Psikososyal Gelişim. Cerrahpaşa T⿰力 Fakültesi Sürekli T⿰力 Eğitimi Etkinlikleri. Semposyum Dizisi, No:63, s.19-21.

Elmacı, N., and Melikşah, E. (2010). Güneydoğu Anadolu Bölgesi’nde Kızların Erken Yaş Evliliklerinin Sosyal ve Kültürel Temelleri. İçinde N. Güngör-Ergan, E. Burcu, B. Şahin, (Ed.) Prof. Dr. Orhan Türkdoğan'a Armă̆an: Sosyoloji Yažlar 2 (223-233). Ankara: Hacettepe Üniversitesi Yayınlar1.

Erol, N. and Duman, N. (2015). Psikososyal açıdan çocuk evlilikleri ve çocuk anneler sorunu, (pp. 58-71). Evlilik Çocuk Oyunu Değil: Çocuk Evlilikler (Ed. Çolakoğlu,B.E.) ANKA Yayınları: Ankara.

Hacettepe Üniversitesi Nüfus Etütleri Enstitüsü. (2008). Türkiye Nüfus ve Sağhk Araştrrması. Ankara: Hacettepe Üniversitesi Nüfus Etütleri Enstitüsü, Sağlık Bakanlığı Ana ve Çocuk Sağlığı ve Aile Planlaması Genel Müdürlüğü, Başbakanlık Devlet Planlama Teşkilatı Müsteşarlığı ve TÜBİTAK.

Hervish, A., and Charlotte, F.J. (2011). Who Speaks For Me. Population Reference Bureau Policy Brief.

Karaşahin, E.,and Ergün, A. (2010).Adolesan gebeliklerde postpartum bakım. Pediatrik ve adolesan Jinekoloji Kitabi. Ed: Berrin A. İstanbul Medikal Yayıncllı, İstanbul, 331-334 
Gök, M. (2016). Child marriages in Turkey with different aspects. International Journal of Human Sciences, 13(1), $2222-2231$. doi:10.14687/ijhs.v13i1.3795

Kurt, A. and Canbulat, N. (2013). Adolesan Dönem Cinselliğiyle Öne Çıkan Serviks Kanseri ve Risk Faktörleri.Medical Journal of Bakırköy. 9( 2):59-63

Oğuzman, K. and Dural, M. (1998). Aile Hukuku. İstanbul: Filiz Kitabevi.

Özcebe, H. and Biçer, B. (2013). Önemli Bir Kız Çocuk ve Kadın Sorunu: Çocuk Evlilikler.Türk Pediatri Arşivi, 48: 8693.

Plan UK (2011). Breaking Vows: Early and Forced Marriage and Girls' Education.

Soylu, N. and Ayaz, M. (2013). Sociodemographic characteristics and psychiatric evaluation of girls who were married at younger age and referred for criminal evaluation, Anadolu Psikiyatri Dergisi.14(2): 136-144.

Kadınlara Karşı Her Türlü Ayrımcılı̆̆ın Önlenmesi Sözleşmesi ve İhtiyari Protokol (2001).T.C. Başbakanlık Kadının Statüsü ve Sorunları Genel Müdürlüğü, UNICEF, Ankara.

The Global Gender Gap Report (2013). Retrieved $10 \quad$ March 2016 from http://www3.weforum.org/docs/WEF GenderGap Report 2013.pdf

TBMM Kadın-Erkek Fırsat Eşitliği Komisyonu. (2010). “Erken Yaşta Evlilikler Hakekında Inceleme Yapılmasına Dair Alt Komisyonun Raporu”. $\quad$ Retrieved $01 \quad 016$ January http://www.tbmm.gov.tr/komisyon/kefe/docs/komisyon rapor.pdf.

UNICEF. (2011). Türkiye'de Çocukların Durumu Raporu. Retrieved 2 May 2015 from http:// panel.unicef.org.tr/vera/app/var/files/s/i/sitan-tur.pdf.

Women in Turkey Report (2015). Aile ve Sosyal Politikalar Bakanlı̆̆1 Kadının Statüsü Genel Müdürlüğü Raporu. Retrieved 2 March 2016 from http://kadininstatusu.aile.gov.tr/uygulamalar/turkiyede-kadin

Yıdız, N. and Avcı, H. (2014). Erken Evlilikelerin Tolumsal Meşruiyeti: Nitel bir Calışma.DİTAM Toplumsal Araştırmalar Merkezi Yayınları: Diyarbakır.

Yıldırım, Y., İnal, M.M., and Tinar, Ş. (2005). Reproductive and Obstetric Characteristics of Adolescent Pregnancies in Turkish Women. Journal of Pediatricand Adolescent Gynecology;18:249-53. 